\section{HIV, syphilis, and hepatitis B and C prevalence among patients with mental illness: a review of the literature}

\author{
Prevalência de infecção por HIV, sífilis e \\ hepatite $B$ e $C$ entre portadores \\ de doenças mentais crônicas
}

\author{
Lorenza Nogueira Campos 1,2 \\ Mark Drew Crosland Guimarães 1,2,3 \\ Ricardo Andrade Carmo 2,4 \\ Ana Paula Souto Melo 1,2,5 \\ Helian Nunes de Oliveira 2,5 \\ Katherine Elkington 3 \\ Karen McKinnon 6
}

\author{
1 Faculdade de Medicina, \\ Universidade Federal de \\ Minas Gerais, Belo Horizonte, \\ Brasil. \\ 2 Grupo de Pesquisas em \\ Epidemiologia e Avaliação \\ em Saúde, Universidade \\ Federal de Minas Gerais, \\ Belo Horizonte, Brasil. \\ 3 HIV Center for Clinical and \\ Behavioral Studies, New York \\ State Psychiatric Institute/ \\ Columbia University, New \\ York City, U.S.A. \\ ${ }^{4}$ Centro de Referência \\ em Doenças Infecciosas \\ e Parasitárias, Secretaria \\ Municipal de Saúdel \\ Universidade Federal de \\ Minas Gerais, Belo Horizonte, \\ Brasil. \\ 5 Instituto Raul Soares, \\ Secretaria de Estado de Saúde \\ de Minas Gerais, \\ Belo Horizonte, Brasil. \\ ${ }^{6}$ New York State Psychiatric \\ Institute, New York City, U.S.A. \\ Correspondence \\ M. D. C. Guimarães \\ Departamento de Medicina \\ Preventiva e Social, \\ Faculdade de Medicina, \\ Universidade Federal de \\ Minas Gerais \\ Av. Prof. Alfredo Balena 190 \\ Belo Horizonte, $M G$ \\ 30130-100, Brasil. \\ mark.guimaraes@gmail.com
}

\section{Introduction}

It is estimated that worldwide at least 33 million people are chronically infected with HIV 1, 170 million with $\mathrm{HCV} 2$, and 350 million with $\mathrm{HBV} 3$, while about 12 million become infected with syphilis each year 4 . Most affected people live in developing countries. These infections have similar transmission routes, mainly by unprotected sex and/or sharing needles or drugs with exchange of blood or body fluids, and they have become a focus of increased public health concern.

By the end of 2001, the World Health Organization (WHO) reported that approximately 450 million people suffered from mental or behavioral disorders, which include four of the 10 leading causes of disability worldwide 5 . The World Bank has estimated an increase from $10.5 \%$ in 1990 to $14.7 \%$ in 2020 in the proportional share of the global burden of disease due to neuropsychiatric disorders. It is also estimated that major depression will rank second, after ischemic heart disease, by $2020{ }^{6}$. These increases are expected to be even higher in developing countries 6 .

Most studies examining these infectious diseases among psychiatric populations have focused on adults with severe mental illness (SMI), the term used to describe a constellation of diagnoses that includes the major psychiatric disorders such as schizophrenia, bipolar disorder, and major depression with psychotic features 7. 
These disorders are characterized by persistent and chronic symptoms and pervasive impairment of function, and typically require periods of hospitalization ${ }^{8}$. There is evidence that persons suffering from SMI are at increased risk of HIV and other sexually transmitted infections (STI) $9,10,11,12,13,14,15$ as compared to other population groups. However, precise and representative prevalence of these infections among persons with SMI has not been clearly established, and there is an even greater lack of data from the developing world.

Therefore, we performed a systematic review of the published literature to describe studies on prevalence of HIV, syphilis, and hepatitis B and $\mathrm{C}$ among patients with chronic mental illness in Brazil and other developing countries and to present findings from studies in developed countries to contextualize what has been learned and what remains to be investigated.

\section{Review of the literature}

\section{Overview}

Reported data on the prevalence of the above infections in this population are highly variable, with heterogeneous criteria for defining key factors such as recruitment site, sample size, use of additional eligibility criteria beyond SMI (i.e. dementia, homelessness, and use of illicit or injection drugs), and definition of serological tests used. Additionally, a limited number of studies have investigated the actual prevalence of these infections within psychiatric populations, by which we mean estimates with reliable external validity based on well-designed epidemiological studies with representative samples of adult patients with chronic rather than severe mental illness, covering inpatients and outpatients as well as developed and developing countries. Most published studies are from developed countries and have been derived from relatively small and non-representative samples of one or more cities. They showed SMI populations with higher prevalence rates for these infections as compared to estimates for the general population in the same regions.

We used MEDLINE and SciELO databases as sources of peer-reviewed publications, plus a manual search of references cited in selected studies. Key words included HIV, syphilis, HCV, $\mathrm{HBV}$, risk factors, and prevalence. We found 13 HIV, syphilis, and hepatitis B and C prevalence studies focusing on psychiatric patients in developing countries and 22 in developed countries. Tables 1 and 2 present the infection rates by country. Taken together, these studies show persons with SMI to be disproportionately affected by HIV/AIDS infection in several countries.

\section{HIV}

Developed countries have demonstrated a wider range of infection rates among psychiatric patients than those found in developing countries. For example, a large North American multi-city study reported $3.1 \%$ HIV seroprevalence in psychiatric patients, with rates varying from $1.7 \%$ to $5 \%$ in rural and metropolitan areas, respectively 11 . These results were several times the estimated $0.3-0.4 \%$ rate in the general population 1 . Himelhoch et al. 16 reviewed HIV prevalence among American veterans with and without SMI and found $1 \%$ and $0.5 \%$, respectively. Klinkenberg et al. 17 studied 172 homeless persons with concurrent SMI and substance use disorders in Saint Louis (USA) and found a 6.2\% HIV rate. In Spain, Fernández-Egea et al. 18 studied 332 acute psychiatric inpatients and found that $1.4 \%$ were HIV-1-positive, while Ayuso-Mateos et al. 19 found that $5.1 \%$ of 390 acute-care psychiatric inpatients were HIV-1-infected.

By contrast, there are few studies on HIV infection among samples of psychiatric patients in developing countries showing relatively narrow ranges of infection. In a study of 948 patients seeking treatment for mental disorders in India 15 , the HIV prevalence was $1.7 \%$, higher than the $0.7 \%$ WHO estimate for the general population of India 1. In Brazil, Almeida \& Pedroso 20 found a $1.6 \%$ HIV prevalence rate among 295 male patients in a psychiatric hospital in Belo Horizonte, Minas Gerais State, while Portella 21 found a $1.46 \%$ HIV rate among 298 patients in a psychiatric unit in Salvador, Bahia State. Guimarães et al. 22 reported a $0.8 \%$ HIV rate in a representative national multi-center sample of adults with chronic mental illness ( $\mathrm{n}=2,238$ ), randomly selected from 26 mental health institutions throughout Brazil. These rates are higher than the national estimate for the adult Brazilian population $(0.6 \%) 1$.

Although most of these studies lack representativeness, they suggest an increased HIV infection rate among persons with SMI as compared to the general population. Further research is necessary to estimate the actual prevalence of HIV infection and determine this population's susceptibility to HIV.

\section{Syphilis}

In late 2001, WHO 4 estimated 12 million new cases of venereal syphilis per year during the pre- 
Prevalence of HIV, syphilis, and hepatitis B and C infection among patients with chronic mental illness in developing countries (ordered by HIV prevalence).

\begin{tabular}{|c|c|c|c|c|c|c|c|c|c|}
\hline Study & $\begin{array}{l}\text { Country/ } \\
\text { Date }\end{array}$ & Study site & $\begin{array}{l}\text { Additional } \\
\text { eligibility } \\
\text { criteria * }\end{array}$ & $\begin{array}{c}\text { Data } \\
\text { collection }\end{array}$ & $\mathbf{N}$ & $\begin{array}{l}\text { HIV } \\
(\%)\end{array}$ & $\begin{array}{l}\text { HBV } \\
(\%)\end{array}$ & $\begin{array}{l}\text { HCV } \\
(\%)\end{array}$ & $\begin{array}{c}\text { Syphilis } \\
\text { (\%) }\end{array}$ \\
\hline Chen 100 & Taiwan/1994 & Inpatients & - & Blood sample & 834 & 0.0 & - & - & - \\
\hline $\begin{array}{l}\text { Guimarães } \\
\text { et al. } 22\end{array}$ & Brazil & $\begin{array}{l}\text { Inpatients/ } \\
\text { Outpatients }\end{array}$ & $\begin{array}{l}\text { National } \\
\text { sample }\end{array}$ & Blood sample & 2,238 & 0.8 & $\begin{array}{c}14.7^{\star \star} \\
\text { and } 1.6 \text { *** }\end{array}$ & 2.6 & 1.12 \\
\hline $\begin{array}{l}\text { Tharyan } \\
\text { et al. } 101\end{array}$ & India/2003 & Inpatients & - & Blood sample & 1,160 & 1.0 & - & - & - \\
\hline Portella 21 & Brazil/2000 & Inpatients & - & Blood sample & 298 & 1.5 & - & - & - \\
\hline $\begin{array}{l}\text { Almeida \& } \\
\text { Pedroso } 20\end{array}$ & Brazil/2004 & Male inpatients & - & Blood sample & 295 & 1.6 & 19.7 & 5.7 & 7.6 \\
\hline Carey et al. 15 & India/2007 & Inpatients & - & Blood sample & 948 & 1.7 & 3.0 \# & - & 3.3 \#\# \\
\hline Dasananjali 102 & Thailand/1994 & Inpatients & $\begin{array}{l}\text { Mentally ill } \\
\text { offenders }\end{array}$ & Blood sample & 325 & 1.8 & - & - & - \\
\hline $\begin{array}{l}\text { Hutchinson } \\
\text { \& Simeon } 103\end{array}$ & $\begin{array}{l}\text { Trinidad and } \\
\text { Tobago/1999 }\end{array}$ & Inpatients & - & Chart review & 1,227 & 6.9 & - & - & - \\
\hline $\begin{array}{l}\text { Acuda } \\
\& \text { Sebit } 104\end{array}$ & $\begin{array}{c}\text { Zimbabwe/ } \\
1996\end{array}$ & Inpatients & - & Blood sample & 143 & 23.8 & - & - & - \\
\hline Chang et al. 29 & Taiwan/1993 & Inpatients & - & Blood sample & 780 & - & 18.1 & 6.8 & - \\
\hline $\begin{array}{l}\text { De Souza } \\
\text { et al. } 28\end{array}$ & Brazil/2004 & Inpatients & - & Blood sample & 408 & - & 22.4 & - & - \\
\hline Kulik 27 & Brazil/1999 & Inpatients & - & Blood sample & 702 & - & 49.1 & - & - \\
\hline Takada et al. 24 & Brazil/2003 & Outpatients & Dementia & Blood sample & 454 & - & - & - & $3.3 \# \#$ \\
\hline
\end{tabular}

* Additional eligibility criteria besides the presence of mental illness;

** Prevalence rate $=14.7 \%$ for anti-HBc;

$\star \star \star$ Prevalence rate $=1.6 \%$ for $\mathrm{HBsAg}$;

\# HBsAg tested only;

\#\# Treponemic tested only.

ceding decade, more than $90 \%$ of which in developing countries. Syphilis is an important medical problem among patients with SMI worldwide, especially because of the neurotropic potential of syphilis. Neurosyphilis can be a reversible cause of dementia and has frequently been under-diagnosed in psychiatric patients. The introduction of penicillin therapy has led to a progressive decline in syphilis-related mortality in psychiatric patients 23 , but neurosyphilis and syphilis infection rates among psychiatric patients remain high. All published studies on syphilis rates in the psychiatric population have come from samples in developing countries. Carey et al. 15 found a 3.3\% syphilis rate among 948 inpatients with psychiatric disorders in India, and Takada et al. 24 studied 275 inpatients with dementia in Salvador, Bahia State, Brazil, and found a similar proportion $(3.3 \%)$ of neurosyphilis. Almeida \& Pedroso 20 described a higher proportion (7.6\%) of reactive VDRL among male SMI patients ( $\mathrm{n}=$ 295) in a psychiatric hospital in Belo Horizonte. Guimarães et al. 22 also found a high prevalence of active syphilis $(1.12 \%)$ in the national sample of psychiatric patients in Brazil.

\section{Hepatitis B and C}

Less public attention has focused on the problem of viral hepatitis among psychiatric patients, even though more than a third of the world population has been infected with $\mathrm{HBV}$ and at least 350 million people have been carriers of HBV worldwide 3 . Although many HBV-infected individuals are lifelong carriers (HBsAg positive, anti-HBc positive), not all can transmit the infec- 
Prevalence of HIV, syphilis, and hepatitis B and C infection among patients with chronic mental illness in developed countries (ordered by HIV prevalence).

\begin{tabular}{|c|c|c|c|c|c|c|c|c|c|}
\hline Study & $\begin{array}{l}\text { Country/ } \\
\text { Date }\end{array}$ & Study site & $\begin{array}{l}\text { Additional } \\
\text { eligibility } \\
\text { criteria * }\end{array}$ & $\begin{array}{c}\text { Data } \\
\text { collection }\end{array}$ & $\mathbf{N}$ & $\begin{array}{l}\text { HIV } \\
(\%)\end{array}$ & $\begin{array}{l}\text { HBV } \\
(\%)\end{array}$ & $\begin{array}{l}\mathrm{HCV} \\
(\%)\end{array}$ & $\begin{array}{c}\text { Syphilis } \\
\text { (\%) }\end{array}$ \\
\hline \multicolumn{10}{|l|}{ Di Nardo } \\
\hline et al. 105 & Italy/1995 & Inpatients & - & Blood sample & 206 & 0 & 47.5 & 0.4 & - \\
\hline \multicolumn{10}{|l|}{ Fernández- } \\
\hline Egea et al. 18 & Spain/2002 & Inpatients & $\begin{array}{c}\text { Acute } \\
\text { psychiatric } \\
\text { patients }\end{array}$ & Blood sample & 332 & 1.0 & 3.2 & 5.1 & - \\
\hline $\begin{array}{l}\text { Himelhoch } \\
\text { et al. } 16\end{array}$ & USA/2007 & $\begin{array}{l}\text { Inpatients/ } \\
\text { Outpatients }\end{array}$ & $\begin{array}{l}\text { Military } \\
\text { veterans }\end{array}$ & Chart review & 191,625 & 1.0 & - & - & - \\
\hline Beyer et al. 106 & USA/2007 & Outpatients & - & Chart review & 11,284 & 1.2 & - & - & - \\
\hline $\begin{array}{l}\text { Rosenberg } \\
\text { et al. } 11\end{array}$ & USA/2001 & $\begin{array}{l}\text { Inpatients/ } \\
\text { Outpatients }\end{array}$ & - & Blood sample & 931 & 3.1 & 23.4 & 19.6 & - \\
\hline $\begin{array}{l}\text { Naber } \\
\text { et al. } 107\end{array}$ & Germany/1994 & Inpatients & - & Blood sample & 623 & 4.8 & - & - & - \\
\hline $\begin{array}{l}\text { Ayuso-Mateos } \\
\text { et al. } 19\end{array}$ & Spain/1997 & Inpatients & - & Blood sample & 390 & 5.1 & - & - & - \\
\hline $\begin{array}{l}\text { Cournos } \\
\text { et al. } 57\end{array}$ & USA/1994 & Inpatients & - & Blood sample & 971 & 5.1 & - & - & - \\
\hline $\begin{array}{l}\text { Cournos } \\
\text { et al. } 9\end{array}$ & USA/1991 & Inpatients & - & Blood sample & 451 & 5.5 & - & - & - \\
\hline $\begin{array}{l}\text { Schartz-Watts } \\
\text { et al. } 108\end{array}$ & USA/1995 & Inpatients & - & Chart review & 220 & 5.5 & - & - & - \\
\hline $\begin{array}{l}\text { Stewart } \\
\text { et al. } 109\end{array}$ & USA/1994 & Inpatients & - & Blood sample & 533 & 5.8 & - & - & - \\
\hline $\begin{array}{l}\text { Klinkenberg } \\
\text { et al. } 17\end{array}$ & USA/2003 & Outpatients & $\begin{array}{l}\text { Homeless; } \\
\text { subst. use } \\
\text { disorders }\end{array}$ & Blood sample & 172 & 6.2 & $32.5^{\star \star}$ & $29.8^{\star \star}$ & - \\
\hline $\begin{array}{l}\text { Zamperetti } \\
\text { et al. } 110\end{array}$ & Italy/1990 & Inpatients & - & Blood sample & 475 & 6.5 & - & - & - \\
\hline $\begin{array}{l}\text { Krakow } \\
\text { et al. } 111\end{array}$ & USA/1998 & Inpatients & $\begin{array}{l}\text { Subst. Use } \\
\text { disorders }\end{array}$ & Blood sample & 147 & 19 & - & - & - \\
\hline Pirl et al. 13 & USA/2005 & Inpatients & - & Chart review & 548 & $29.0 * \star \star$ & 23.9 & 21.5 & - \\
\hline $\begin{array}{l}\text { Tabibian } \\
\text { et al. } 26\end{array}$ & USA/2007 & Inpatients & - & Blood sample & 129 & - & 16.0 & 38.0 & - \\
\hline $\begin{array}{l}\text { Butterfield } \\
\text { et al. } 31\end{array}$ & USA/2003 & Inpatients & $\begin{array}{l}\text { Military } \\
\text { veterans }\end{array}$ & Blood sample & 376 & - & 21.3 & 18.9 & - \\
\hline Lohiya et al. 25 & USA/1986 & $\begin{array}{l}\text { Inpatients/ } \\
\text { Outpatients }\end{array}$ & - & Blood sample & 1,149 & - & 66.0 & - & - \\
\hline $\begin{array}{l}\text { Freudenreich } \\
\text { et al. } 30\end{array}$ & USA/2007 & Outpatients & Schizophrenia & Blood sample & 98 & - & - & 8.2 & - \\
\hline $\begin{array}{l}\text { Dinwiddie } \\
\text { et al. } 112\end{array}$ & USA/2003 & Outpatients & - & Blood sample & 1,556 & - & - & 8.5 & - \\
\hline $\begin{array}{l}\text { Buttterfield } \\
\text { et al. } 113\end{array}$ & USA/2004 & $\begin{array}{l}\text { Inpatients/ } \\
\text { Outpatients }\end{array}$ & - & Blood sample & 777 & - & - & 15.7 & - \\
\hline Meyer 114 & USA/2003 & Inpatients & - & Chart review & 507 & - & - & 20.3 & - \\
\hline
\end{tabular}

* Additional eligibility criteria besies the presence of mental illness;

** Among 114 participants tested for anti-HBc and anti-HCV;

*** Among 62 participants tested for anti-HIV. 
tion and a large proportion may clear the virus after varying intervals (HBsAg negative, anti$\mathrm{HBc}$ positive).

Individuals with SMI have been shown to be at increased risk for acquiring HBV and HCV infections in both developing and developed countries. Tables 1 and 2 show the high prevalence of HBV markers among individuals with SMI, which varies considerably. While Lohiya et al. 25 and Klinkenberg et al. 17 found a prevalence of HBV markers of $66 \%$ and $32.5 \%$, respectively, Tabibian et al. 26 found $16 \%$.

In Brazil, Kulik 27 found a $49.1 \%$ HBV prevalence rate, De Souza et al. 28 22.4\%, and Almeida \& Pedroso 20 19.7\%, while Guimarães et al. 22 found a prevalence of $1.64 \%$ and $14.7 \%$ for previous exposure and active HBV infection, respectively. In Taiwan, Chang et al. ${ }^{29}$ reported an HBV prevalence rate of $18.1 \%$, and in India, Carey et al. 15 found a $3 \%$ active HBV infection rate.

One reason for the wide range of HBV prevalence rates is the choice of serological markers used by researchers. Several authors have studied prior exposure to HBV (anti-HBc positive) while others used current HBV infection (HBsAg positive). HBV prevalence also differs by geographic region. Higher HBV prevalence rates are present in Asia, Africa and South America, for example, than in the United States. Finally, most of these studies sampled only a specific psychiatric center and thus do not represent their respective national psychiatric populations.

HCV infection presents a different epidemiological picture from HBV. However, there is also wide variability of HCV prevalence rates in the psychiatric population. Some researchers in the United States have found HCV exposure rates as high as $38 \% 26$, and others as low as $8.2 \% 30$. The lowest HCV rates were found in developing countries, with $2.63 \% 22$ and $5.7 \%$ in Brazil 20 and $6.8 \%$ in Taiwan 29. The wide range in HCV prevalence may be related to different patterns of injection drug use and needle-sharing among individuals with SMI as well as geographic differences in prevalence in the general population.

\section{Sociodemographic risk factors for HIV and STI}

Some studies have investigated the role of sociodemographic factors in the increased risk of HIV and other STI among individuals with SMI. However, most studies come from developed countries, and not all sociodemographic characteristics were studied consistently or were reported with sufficient methodological detail. Lack of representativeness has also been common.
Several investigators in developed countries have suggested that women may be at higher risk of HIV infection among patients with SMI 9,31,32,33, although others have described a higher likelihood of HIV infection in men 16,34. However, not all these studies analyzed gender differences in psychiatric diagnoses and other associated factors. While some authors have identified an increased risk of HIV and other STI among younger patients with chronic mental illness $33,35,36$, others have reported increased risk among adult and older patients 16. Other sociodemographic factors that have been associated with increased risk of HIV infection are never having been married, being divorced or widowed 16,36; ethnicity (Hispanic or African-American) 9,16,35; receiving care in urban settings 16; or homelessness 16.

In terms of hepatitis, older age was consistently reported as a risk factor for HBV across countries with different degrees of development $11,17,37,38$. Other risk factors for hepatitis B infection among people with intellectual disability were described such as male gender, older age, and geographic region 38. Other risk factors for hepatitis $\mathrm{C}$ infection in psychiatric patients were increasing age $11,13,17$ and male gender 17,34. Butterfield et al. 31 conducted a large study with 777 patients with SMI to investigate gender differences in hepatitis $\mathrm{C}$ infection. The authors concluded that male gender did not contribute independently to the risk of hepatitis C infection, whereas age and needle sharing were significantly related to hepatitis $\mathrm{C}$ serological status. The higher rates of hepatitis $\mathrm{C}$ in men can be explained primarily by more lifetime exposure to injection drug use, specifically needle sharing.

\section{Sexual behavior and risk of HIV and STI}

Sexual transmission is the most common route of HIV infection worldwide 1, and adults with SMI are at particular risk. Studies consistently show that this population is sexually active, and the majority engages in high rates of sexual risk behaviors 39 . Sexual practices that can increase the risk of acquiring HIV include: unprotected vaginal or anal sexual intercourse, sex with multiple partners, sex with partners at high risk for HIV (e.g. injection drug users and sex workers), or sex exchange practices. In order to intervene successfully and decrease risk among this population, it is important to understand patterns of risk behaviors and which specific behaviors are associated with greater likelihood of HIV infection.

In addition, high rates of comorbid alcohol and drug use disorders are found among per- 
sons with SMI 40, but we did not review that literature here. Nevertheless, substance use may be a common part of the sexual experience of persons with SMI 41,42 , so it is also important to examine the HIV sexual risk behaviors associated with the effects of substance use, such as sex while drunk or high. Sexual intercourse under the influence of alcohol or other drugs is often unplanned, and is associated with having sex with risky partners, lower condom use, and decreased ability to negotiate safe sex practices 42. Substance use in other populations is also highly correlated with exchanging sex for drugs, money, shelter, etc., greatly increasing the risk of HIV transmission 43.

\section{Sexual activity}

In developed countries, between $51 \%$ and $74 \%$ of adults with SMI report being sexually active within the previous 12 months 39,44; this rate ranged from $32 \%$ to $65 \%$ in the previous 3 months $14,39,45,46$. Meade \& Sikkema 40 in their recent review of sexual risk behaviors among persons with SMI found that, on average, a larger proportion of persons with SMI in the United States were sexually active as compared to studies in Australia, New Zealand, and Italy.

In developing countries, rates of sexual activity were lower than the ranges found in developed countries. In Brazil, Guimarães et al. 22 found that $61.6 \%$ of inpatients and outpatients reported sexual intercourse at least once in the previous six months. Using a measure with demonstrated reliability among outpatients in Rio de Janeiro, Wainberg et al. 47 found that $42 \%$ of 98 patients had engaged in vaginal or anal sex within the previous three months. The lowest rate of sexual activity among psychiatric inpatients was found in India, where $41 \%$ had been sexually active in the previous 2 years 48 .

Between $2 \%$ and $10 \%$ of individuals with SMI reported having anal sex in the previous year $49,50,51,52,53$. Studies assessing the prevalence of anal sex during the previous 10 years or longer (i.e. lifetime) among adults with SMI found that $13 \%$ to $84 \%$ had ever engaged in this behavior 8 , $42,44,54,55,56,57,58,59,60,61,62$. These high lifetime rates of anal sex are particularly alarming. Susser et al. 63 found that a lifetime history of male-male sex among homeless males with SMI in the United States was associated with more than a threefold increase of being HIV positive, a finding replicated in other studies 64 . Although reliability of sexual behavior reports beyond six months in the past has not been established, a review of studies examining HIV seroprevalence among individuals with SMI found that across 11 studies, approximately one in four of those with a history of male-male sex were HIV-positive 65 .

All the above studies, which span the past 14 years and several countries, clearly demonstrate that individuals with SMI are not in fact asexual but are a sexually active population, at potential risk of HIV/AIDS through risky sexual practices.

\section{Condom use}

Alarmingly, sexually active adults with SMI use condoms inconsistently. Between $12 \%$ and $68 \%$ reported inconsistent condom use in the previous 12 months 14,39,44,49,51,54,55,66, and 43\%-78\% reported any unprotected sex in the previous 3 months 39,46 . Inversely, between $8 \%$ and $63 \%$ reported consistent condom use in the previous 12 months 39,44 , with the highest rate found in a sample of HIV-positive persons with SMI 44 . Rates of unprotected sex are much higher for adults with SMI who engage in anal sex or have partners who are HIV-positive. Over $70 \%$ and $85 \%$ of these sexual events, respectively, were reported to be unprotected in U.S. samples 52,67.

Males with SMI report more condom use than females. An Australian study found that approximately $15 \%$ of males compared to only $2 \%$ of females with SMI always use condoms with a casual or non-primary partner 51 . However, over three-fourths of both males and females reported never using condoms with main partners 51 . Similarly, a U.S. study found that women with SMI had significantly more unprotected vaginal intercourse than their male counterparts 67 .

In Brazil, Guimarães et al. 22 and Wainberg et al. 47 found that only $16 \%$ and $22 \%$ of sexually active participants used condoms consistently in the previous six and three months, respectively. In one study conducted in Minas Gerais, $68.2 \%$ of the sexually active sample of male inpatients reported not using condoms 20 . These are the only data on condom use in the psychiatric population from a developing country.

\section{Multiple partners}

Having multiple sex partners also increases the risk of HIV/AIDS infection, but there are few studies on this direct association in psychiatric populations. Rosenberg et al. 8 noted that having multiple partners in the previous 6 months more than doubled the likelihood of being HIVpositive (non-significant trend) or HBV-positive (significant).

However, because of the high prevalence of multiple partners among individuals with SMI, the potential for HIV transmission is great. Between $7 \%$ and $69 \%$ of psychiatric samples report- 
ed having two or more partners in the previous 12 months $14,39,44$, and $13 \%$ to $46 \%$ in the previous 3 months 39,46 . Again, in developing countries data are scarce on multiple partners. In Brazil, $26.8 \%$ of psychiatric outpatients reported having multiple partners in the previous 3 months 47 . Further research is need to better ascertain the role of multiple partners as a risk factor for HIV among individuals with SMI.

\section{High-risk partners}

High-risk partners are those who are known or thought to be HIV-positive, to use intravenous drugs, to share needles with other partners, to be sexually active with other partners, to have unprotected sex with other partners, or to engage in sex trade with other partners 50,54,66,67,68. In their review of 11 studies, Cournos \& McKinnon 65 found that over one-third of adults with SMI who reported sex with a high-risk partner (e.g. IDU) were HIV-positive.

Among adults with SMI in developed countries, between $2 \%$ to $58 \%$ identified having sex with a high-risk partner in the previous 3 to 12 months $44,47,50,51,54,60,68,3 \%$ to $14 \%$ had sexual intercourse with an IV drug user 50,51,54,60,67, 9\% to $58 \%$ had sex with a non-monogamous partner $51,54,67$, and $23 \%$ had ever had a partner who was a sex worker 61 . Between $1 \%$ and $7 \%$ reported ever having sex with someone who was HIV-positive $51,60,61$. Thompson et al. 61 examined differences between males and females in prevalence of types of risky partners (e.g. sex worker, IDU, HIVpositive) over the previous 10 years and found no differences by gender.

In Brazil, the only developing country from which data were found, $53.7 \%$ of individuals with SMI reported having high-risk partners or partners whose HIV status was unknown, and 7.3\% reported having a known HIV-positive partner 47, while Almeida \& Pedroso 20 found that $20.1 \%$ of male psychiatric inpatients reported having a risky partner.

\section{Sex exchange}

Individuals with SMI frequently have lower socioeconomic status and are sometimes homeless or addicted to drugs or alcohol; sexual services can be a means of obtaining food, shelter, money, and/or drugs 41 . Trading sex is a particularly worrisome behavior since it is highly correlated with other HIV/AIDS risk behaviors: drug use, sex with high-risk partners, decreased condom use, and higher rates of IDU and needle sharing 39. Rosenberg et al. 11 found that individuals with mental illness who ever traded sex for money and/or drugs were more than 5 times more likely to be infected with HIV and approximately twice as likely to have HBV and HCV. In their review of 11 studies, Cournos \& McKinnon 65 found that almost $40 \%$ of those who engaged in sex exchange were HIV-positive.

In developed countries, between $2 \%$ and $42 \%$ of adults with SMI reported exchanging sex within the previous 12 months 14,39,44; between $5 \%$ and $38 \%$ reported this behavior within the previous 3 months 46,68. In a sample of Australian inpatients and outpatients, while almost $50 \%$ of males (and $0 \%$ of females) reported ever paying for sex, similar rates of men (13\%) and women (15\%) reported exchanging sex for money and drugs 61 .

Few studies from developing countries examined commercial sex rates. In Brazil, commercial sex was reported by $19.5 \%$ of psychiatric outpatients in Rio de Janeiro 47 and by $2.6 \%$ of male psychiatric inpatients in Minas Gerais 20. In a sample of inpatients in India, $66 \%$ of males compared to $0 \%$ of females had ever traded money for sex. In contrast, $27 \%$ of women and $9 \%$ of men reported traded sex for money 69 . This suggests that females with SMI may be more likely than males to engage in "survival sex" as a means to obtain money, food, or shelter.

\section{Sex while drunk or high}

Between $5 \%$ and $45 \%$ of adults with SMI in developed countries used drugs or alcohol either prior to or during a sexual experience in the previous 12 months $41,50,52,53,54,60,70$. Use of substances prior to sexual activity is significantly related to the presence of other HIV/AIDS risk behaviors. Adults with SMI who had at least one risk behavior were two times more likely to use alcohol during sex 52 . Risky behaviors were also associated with use of specific substances among males and females with SMI. Among males with SMI, inconsistent condom use and sex with a high-risk partner was significantly associated with the use of crack or alcohol before sex; having sex with a high-risk partner was significantly associated with cocaine use. Among females with SMI, alcohol use before sex was associated with receptive anal sex ${ }^{71}$. Moreover, adults with SMI who expect alcohol to increase the likelihood of engaging in risky sex were more likely to do so 72 . These studies suggest that individuals with SMI frequently use substances before or during sex, placing themselves at risk of HIV/AIDS.

In Brazil, the single developing country to examine this phenomenon among psychiatric patients, 39\% of outpatients with SMI reported some type of alcohol or drug use during sex 47 . 


\section{Substance use disorder and risk of HIV and STI}

It is important to differentiate between use and abuse and dependence, which are disorders. The use of psychoactive substances, alcohol, and other drugs is common in the general population and is especially prevalent among persons with SMI. Use of alcohol and other drugs may or may not be a consequence of a mental disorder. Patients with mental disorders such as schizophrenia, bipolar disorder, depression, anxiety, anti-social personality disorder, among others, have high proportions of other psychiatric comorbidities related to the abuse or dependence of psychoactive substances, and their occurrence can vary from 25 to $65 \% 73,74$. Alcohol and other drugs can produce significant effects on cognitive function, mood, sensory perception, and behavior. It can also contribute to decreased therapeutic effects or increased odds of adverse effects related to psychiatric drugs, with implications for the therapeutic approach, the organization of services, and increased treatment costs 75,76 .

Few studies have specifically investigated the association between the use of alcohol and other drugs and risk behavior for sexually transmitted infections, especially HIV, among individuals with SMI. An important limitation is the inability to establish a cause-and-effect relationship. Samples of individuals with SMI are small and in large part restricted to specialized health centers $8,11,32,45,52,59,71,77,78$

IDU among people with severe mental disorder is very common in the United States, possibly exceeding 25\% 11,41,60,67,79. Patients with SMI who report alcohol and other drug abuse or dependencebecome particularlyvulnerable to HIV,HBV, and HCV infection due to risky sexual behavior and a history of IDU 9,11,80,81,82. IDU appears to be a more common risk factor for $\mathrm{HIV}, \mathrm{HBV}$, and $\mathrm{HBC}$ among patients with SMI, as compared to the general population. In the United States, the IDU prevalence is $1.4 \%$ in the general population 83 , lower than estimates among people with SMI, who reported $4 \%$ to $7 \%$ in the previous year and $5 \%$ to $35 \%$ lifetime ${ }^{41}$. Furthermore, IDU appears to be associated with high-risk sexual behavior. IDU psychiatric patients have a higher number of sexual partners 84 and increased odds of trading sex for money or drugs 60 , of having sex with unknown partners, and of not using condoms during sexual intercourse 41,42,85.

SMI inpatients with a history alcohol and other drug use have higher risk of HIV infection, even if they have no history of IDU 85 . However, there is no sufficient evidence in the current scientific literature of a direct association between use of alcohol and other drugs and high-risk sexual behavior or STI, including HIV among individuals with SMI 8,11,45,52. More studies are needed to investigate associations between the risk of HIV infection and other STI and psychoactive substance use among individuals with SMI.

The only studies to examine these relationships in a developing country were conducted in Brazil. Almeida \& Pedroso 20 reported that psychiatric patients who report alcohol and other drug abuse were particularly vulnerable to HCV infection. Wainberg et al. 47 elicited injection histories among 98 psychiatric outpatients with SMI; none reported even a single occasion of injection drug use.

\section{Psychiatric conditions and risk of HIV and STI}

Investigators in both developed and developing countries have found that patients diagnosed with a schizophrenia-spectrum disorder are less sexually active than patients with any other category of psychiatric diagnoses $36,42,53,69$. However, it is not clear whether or how sexuality or sexual risk-taking is affected by psychiatric illness, and it cannot be assumed that all aspects of the sexual lives of psychiatric patients are only expressions of their mental disorders. No data on normative sexuality in this population has been published. Studies on the effects of psychiatric conditions on sexual risk behavior have not been undertaken in developing countries.

In the United States, individuals diagnosed with a schizophrenia-spectrum disorder were less likely than patients with a mood disorder to engage in sexual risk behavior 32 . However, trading sex was more than three times as likely among patients with schizophrenia than among those with others diagnoses 42 .

It has been theorized that patients with bipolar disorder may experience hypersexuality during the acute phase of their illness 81 . Other authors described heightened sexuality among patients with bipolar disorder during the manic phase 41,80 . In addition, patients diagnosed with personality disorders appear to be at higher risk of HIV infection than patients diagnosed only with an Axis I clinical syndrome 60,80. Moreover, persons in whom both Axis I and Axis II disorders are diagnosed as well as those presenting with positive symptoms appear to be at greater HIV behavioral risk 86 .

According to a review by Otto-Salaj \& Stevenson 86 , bipolar disorder and schizophrenia appear to be related to increased HIV risk. However, in a review by Cournos \& Mckinnon 65, di- 
agnosis was not consistently associated with HIV serostatus. Moreover, psychiatric diagnosis has been shown consistently to be unrelated to condom use 42,55,56,59,87,88,89, multiple sexual partners $53,58,59,77,88$, history of STI 77 , or risk of HIV infection $10,35,36,49,69,80,90,91,92$.

Although psychiatric diagnosis per se has not been associated with sexual risk behavior 39 , the presence of psychiatric symptoms appears in several studies to be more predictive of higher rates of sexual risk behavior compared to psychiatric diagnoses. Cournos et al. 58 investigated a group of 95 patients with schizophrenia and found that higher levels of positive symptoms were associated with multiple sexual partners, and greater overall psychopathology was significantly correlated with sexual activity. McKinnon et al. ${ }^{42}$, in their sample of 178 patients with SMI, reported that increased occurrence of positive symptoms was significantly associated with multiple sexual partners. Also, trading sex was more than five times as likely among those with more excitement symptoms, and the presence of more excitement symptoms and fewer cognitive symptoms predicted increased sexual activity. However, no association could be demonstrated between any specific symptom and condom use. Similarly, Rosenberg et al. 8 reported that greater psychiatric distress, assessed by the Symptom Checklist-90-R, predicted a higher risk of HIV infection. Findings from different studies are not easily comparable, because measures of psychiatric diagnoses and specific risk behaviors were often non-standardized ${ }^{8}$. Carey et al. ${ }^{41}$ have discussed the use of psychiatric diagnosis based on information registered in medical charts rather than the use of structured interviews or standardized research criteria as well as the use of convenience samples, which can produce inconsistent data.

\section{HIV/AIDS knowledge and risk of HIV and STI}

Studies evaluating the level of knowledge on HIV/AIDS in psychiatric populations have been conducted primarily in developed countries. Overall knowledge scores ranged from $63 \%$ to $80 \%$, which appear to be relatively good, and even comparable to those found in the general population 12,42,67. However, specific knowledge deficits also have been found $32,41,70,93,94$. For example, Kelly et al. 82 reported that many individuals with SMI were uninformed about practical aspects of HIV risk reduction: for example, $43 \%$ believed that heterosexual women could not get AIDS. Bear et al. 95 found that knowledge deficits concerning HIV/AIDS were relatively common in the psychiatric setting. Carey et al. ${ }^{41}$ found that many psychiatric patients were misinformed regarding HIV transmission, risk reduction, and AIDS. Strauss ${ }^{96}$ reported high rates of inaccurate HIV knowledge among American veterans with SMI, with $40 \%$ of patients demonstrating some inaccuracies.

Despite clear instances where knowledge in this population could be improved, to date there is little evidence that deficits in AIDS knowledge are associated with risk behavior or risk reduction. Zafrani \& McLaughlin 84 found an association between lower AIDS knowledge and greater risk behavior, although other authors have not corroborated this finding 90,92. McKinnon et al. 42 found that knowledge alone did not predict any risk behavior. Meanwhile, some authors have reported that individuals that engaged in high-risk sexual behaviors correctly perceived themselves to be at higher risk of HIV infection $39,41,67,68$, and that risk behavior often occurs in the context of misinformation about HIV/AIDS 60. Nevertheless, Vanable et al. 97 found a higher level of knowledge on HIV/AIDS among psychiatric patients who reported a history of any STI.

Other associations with lower knowledge on HIV/AIDS among psychiatric patients have been described in the literature, including being diagnosed with schizophrenia-spectrum diseases $62,89,91$, impaired cognitive function ${ }^{4}$, more than six years of mental illness ${ }^{93}$, history of more than four psychiatric hospitalizations 93 , and negative symptoms 42,98. Although McKinnon et al. 42 found no association between knowledge and socioeconomic variables, another study with American veterans reported that psychiatric patients with less than 12 years of education, older age, unmarried, or with no history of homelessness in the previous six months showed lower knowledge about HIV/AIDS 96.

In the only two developing countries where HIV knowledge has been assessed among psychiatric patients, researchers in Nigeria found that knowledge among psychiatric patients was worse than in the general population ${ }^{94}$, and in Brazil Wainberg et al. 47 found a mean $( \pm$ SD) HIV knowledge score of $10.4 \pm 3.3$, corresponding to a $61.2 \%$ correct response rate.

Despite many conflicting reports in the literature, well-designed studies are needed to further clarify the role of knowledge on HIV/AIDS among psychiatric patients, since some intervention models have proposed to offer information on HIV/AIDS as a potential tool for reducing risk behaviors for acquisition of HIV and other STI 99. Our position is that improving the knowledge on HIV/AIDS in this population is a prerequisite for 
changing risk behaviors and an important initial step towards HIV/AIDS prevention.

\section{Conclusions}

This review highlights the lack of information regarding STI prevalence and associated factors among person with chronic mental illness worldwide, but especially in developing countries. Most of the published studies on this population are from developed countries and are based on relatively small and non-representative samples. Overall, the prevalence rates warrant more rigorous studies in order to understand whether and why people with SMI are at particular risk for STI acquisition or transmission and how to address the particular prevention and sexual health needs individuals with chronic mental illness. HIV, which has been shown to disproportionately affect certain psychiatric subgroups in both developed and developing countries, has been the impetus for understanding other infections in the psychiatric population with similar

\section{Resumo}

Os portadores de doenças mentais crônicas encontramse em risco para a infecção pelo HIV e outras infecções sexualmente transmissíveis. Entretanto, a prevalência dessas infecções entre portadores de doença mental crônica ainda não está claramente estabelecida nesta população. A maioria dos trabalhos sobre o tema foi conduzida em países desenvolvidos, com amostras relativamente pequenas e não representativas. Foi realizada uma revisão sistemática da literatura para identificar estudos sobre a prevalência do HIV, sífilis, hepatite B e C entre pacientes com doença mental crônica no Brasil e no mundo. De um modo geral, as prevalências variaram de 0\% a 29\%, 3 a 66\%, 0,4 a 38\% e 3,3\% a 7,6\% para HIV, hepatite B, hepatite C e siffilis, respectivamente. Vários fatores de risco foram identificados e discutidos, embora a literatura atual não demonstre achados significativos gerados por estudos representativos. Tal revisão destaca a escassez de informação sobre a prevalência de infecções sexualmente transmitidas e seus fatores associados entre portadores de doenças mentais crônicas e identifica lacunas no conhecimento atual em países desenvolvidos bem como nos em desenvolvimento.

Pessoas Mentalmente Doentes; Doenças Sexualmente Transmissíveis; HIV routes of transmission. HBV is often neglected because of its largely asymptomatic course, but its long-term complications and the availability of safe, effective, and cost-effective vaccines for nearly 20 years argue for more rigorous research on infection rates in the psychiatric population worldwide. HCV, discovered in 1989, has similar risk factors and is also a cause of chronic hepatitis. A similar paucity of prevalence data in the psychiatric population outside the United States, where rates are alarmingly high, represents an urgent public health problem. Given the existence of effective treatment and the possibility of cure for syphilis, we strongly recommend systematic testing for this disease among all psychiatric patients in order to rule out this biological cause of symptoms and to treat positive cases to reverse dementia.

Finally, the available evidence, although incomplete, suggests that the sexual health and well-being of psychiatric patients require greater attention. It is time to effectively include this population in our public health endeavors.

\section{Contributors}

L. N. Campos was responsible for supervising and coordinating the teamwork, revising and editing the text, and writing the section on sociodemographic risk factors. M. D. C. Guimarães revised the entire manuscript. R. A. Carmo was responsible for writing the section on HBV, HCV, syphilis, and HIV seroprevalence rates. A. P. S. Melo was responsible for writing the section on psychiatric conditions and knowledge on HIV/AIDS. H. $\mathrm{N}$. Oliveira was responsible for writing the section on substance use disorders. K. Elkington was responsible for writing the section on sexual behavior. K. McKinnon revised the entire manuscript. 


\section{References}

1. Joint United Nations Programme on HIV/AIDS. AIDS epidemic update: December 2007. Geneva: World Health Organization; 2007.

2. World Health Organization. Hepatitis C. Geneva: World Health Organization; 2002.

3. World Health Organization. Hepatitis B. Geneva: World Health Organization; 2004.

4. World Health Organization. Global prevalence and incidence of selected curable sexually transmitted infections: overview and estimates. Geneva: World Health Organization; 2001

5. World Health Organization. The World Health Report 2001. Mental health: new understanding, new hope. Geneva: World Health Organization; 2001.

6. Murray CJL, Lopez AD. Alternative projections of mortality and disability by cause 1990-2020: global burden of disease study. Lancet 1997; 349: 1498-504.

7. Schimnar A, Rothbard A, Kanter R, Jung Y. An empirical literature review of definitions of severe and persistent mental illness. Am J Psychiatry 1990; 147:1602-8.

8. Rosenberg SD, Trumbetta SL, Mueser KT, Goodman LA, Osher FC, Vidaver RM, et al. Determinants of risk behavior for human immunodeficiency virus/ acquired immunodeficiency syndrome in people with severe mental illness. Compr Psychiatry 2001; 42:263-71.

9. Cournos F, Empfield M, Horwath E, McKinnon K, Meyer I, Schrage H, et al. HIV seroprevalence among patients admitted to two psychiatric hospitals. Am J Psychiatry 1991; 148:1225-30.

10. Sacks M, Dermatis H, Looser-Ott S, Perry S. Seroprevalence of HIV and risk factors for AIDS in psychiatric inpatients. Hosp Community Psychiatry 1992; 43:736-7.

11. Rosenberg SD, Goodman LA, Osher FC, Swartz MS, Essock SM, Butterfield MI, et al. Prevalence of HIV, hepatitis $\mathrm{B}$, and hepatitis $\mathrm{C}$ in people with severe mental illness. Am J Public Health 2001; 91:31-7.

12. McKinnon K, Cournos F, Herman R. HIV among people with chronic mental illness. Psychiatr Q 2002; 73:17-31.

13. PirlW, Greer J, Weissgarber C, Liverant G, Safren SA. Screening for infectious diseases among patients in a state psychiatric hospital. Psychiatr Serv 2005; 56:1614-6.

14. Meade C, Sikkema KJ. Psychiatric and psychosocial correlates of sexual risk behavior among adults with severe mental illness. Community Ment Health J 2007; 43:153-69.

15. Carey M, Ravi V, Chandra P, Desai A, Neal DJ. Prevalence of HIV, hepatitis B, syphilis, and Chlamydia among adults seeking treatment for a mental disorder in Southern India. AIDS Behav 2007; 11: 289-97.

16. Himelhoch S, MacCarthy J, Ganoczy D, Medoff D, Dixon LB, Blow FC. Understanding associations between serious mental illness and HIV among patients in the VA health system. Psychiatr Serv 2007; 58:1165-72.
17. Klinkenberg W, Caslyn R, Morse G, Yonker RD, McCudden S, Ketema F, et al. Prevalence of human immunodeficiency virus, hepatitis B and hepatitis $\mathrm{C}$ among homeless persons with co-occurring severe mental illness and substance use disorders. Compr Psychiatry 2003; 44:293-302.

18. Fernández-Egea E, Gil E, Santomá S, Baró MS, Andreu JB, Miyar MV. Serological testing and prevalence of human immunodeficiency, hepatitis $\mathrm{B}$ and $\mathrm{C}$ virus infections amongst acute psychiatric inpatients. Med Clin (Barc) 2002; 119:690-2.

19. Ayuso-Mateos J, Montañés F, Lastra I, La Garza JJP, Ayuso-Gutiérrez JL. HIV infection in psychiatric patients: an unlinked anonymous study. Br J Psychiatry 1997; 170:181-5.

20. Almeida RC, Pedroso ERP. Vulnerabilidade e exposição a marcadores sorológicos dos vírus da imunodeficiência humana, hepatites B e C, vírus linfotrópico de células $\mathrm{T}$ humanas e sífilis em pacientes psiquiátricos internados em hospital público. Rev Assoc Méd Minas Gerais 2004; 14:244-50.

21. Portella PG. Perfil epidemiológico da infecção pelo HIV em um hospital psiquiátrico de Salvador [Master's Thesis]. Salvador: Universidade Federal da Bahia; 2000.

22. Guimarães MDC, Campos LN, Melo APS, Carmo RA, Machado CJ. Prevalence of HIV, syphilis, hepatitis $\mathrm{B}$ and $\mathrm{C}$ among adults with chronic mental illness: a national multicenter study in Brazil. In: Proceedings of the 18th World Congress of Epidemiology. Porto Alegre: ABRASCO; in press.

23. Costa GF. Neurosyphilis mortality in a psychiatric hospital over a 50 -year period. Arq Neuropsiquiatr 1984; 42:20-4.

24. Takada L, Caramelli P, Radanovic M, Anghinah R, Hartmann AP, Guariglia CC, et al. Prevalence of potentially reversible dementias in a dementia outpatient clinic of a tertiary university-affiliated hospital in Brazil. Arq Neuropsiquiatr 2003; 61:925-9.

25. Lohiya S, Ghanshyam L, Caíres S. Epidemiology of hepatitis B infection in institutionalized mentally retarded clients. Am J Public Health 1986; 76:799802.

26. Tabibian JH, Wirshing DA, Pierre JM, Guzik LH, Kisicki MD, Danovitch I, et al. Hepatitis B and C among veterans on a psychiatric ward. Dig Dis Sci 2008; 53:1693-8.

27. Kulik SM. Estudo descritivo para hepatite B em portadores de deficiência mental e em profissionais de saúde em instituição fechada no Brasil [Master's Thesis]. São Paulo: Universidade de São Paulo; 1999.

28. De Souza MM, Barbosa MA, Borges AM, Daher RR, Martins RM, Cardoso DD. Seroprevalence of hepatitis $B$ virus infection in patients with mental problems. Rev Bras Psiquiatr 2004; 26:34-7.

29. Chang TT, Lin H, Yen YS, Wu HL. Hepatitis B and hepatitis $\mathrm{C}$ among institutionalized psychiatric patients in Taiwan. J Med Virol 1993; 40:170-3.

30. Freudenreich O, Rajesh G, Walsh J, Henderson DC, Goff DC. Hepatitis C in schizophrenia: screening experience in a community-dwelling clozapine cohort. Psychosomatics 2007; 48:405-11. 
31. Butterfield MI, Boswroth HB, Meador KG, Stechuchak KM, Essock SM, Osher FC, et al. Gender differences in hepatitis $\mathrm{C}$ infection and risks among persons with severe mental illness. Psychiatr Serv 2003; 54:848-53.

32. Carey M, Carey K, Maisto S, Schroder KE, Vanable PA, Gordon CM. HIV risk behavior among psychiatric outpatients: association with psychiatric disorder, substance use disorder, and gender. J Nerv Ment Dis 2004; 192:289-96.

33. Empfield M, Cournos F, Meyer I, McKinnon K, Horwath E, Silver M, et al. HIV seroprevalence among homeless patients admitted to a psychiatric inpatient unit. Am J Psychiatry 1993; 150:47-52.

34. Essock SM, Dowden S, Constantine NT, Katz L, Swartz MS, Meador KG, et al. Risk factors for HIV, hepatitis $\mathrm{B}$, and hepatitis $\mathrm{C}$ among persons with severe mental illness. Psychiatr Serv 2003; 54: 836-42.

35. Hellerstein DJ, Prager ME. Assessing HIV risk in the general hospital psychiatric clinic. Gen Hosp Psychiatry 1992; 14:3-6.

36. Carey MP, Carey KB, Maisto SA, Gordon CM, Vanable PA. Prevalence and correlates of sexual activity and HIV-related risk behavior among psychiatric outpatients. J Consult Clin Psychol 2001; 69: 846-50.

37. Alvarado-Esquivel C, Arreola-Valenzuela MA, Mercado-Suárez MF, Espinoza-Andrade F. Hepatitis $B$ virus infection among inpatients of a psychiatric hospital of Mexico. Clin Pract Epidemol Ment Health 2005; 1:10.

38. Vellinga A, Van Damme P, Meheus A. Hepatitis B and $\mathrm{C}$ in institutions for individuals with intellectual disability. J Intellect Disabil Res 1999; 43: 445-53.

39. Meade C, Sikkema KJ. HIV risk behavior among adults with severe mental illness: a systematic review. Clin Psychol Rev 2005; 25:433-57.

40. RachBeisel J, Scott J, Dixon L. Co-occurring severe mental illness and substance use disorders: a review of recent research. Psychiatr Serv 1999; 50:1427-34

41. Carey MP, Carey KB, Kalichman SC. Risk for human immunodeficiency virus (HIV) infection among persons with severe mental illnesses. Clin Psychol Rev 1997; 17:271-91.

42. McKinnon K, Cournos F, Sugden R, Guido JR, Herman $R$. The relative contributions of psychiatric symptoms and AIDS knowledge to HIV risk behaviors among people with severe mental illness. J Clin Psychiatry 1996; 57:506-13.

43. Logan TK, Cole J, Leukefeld C. Women, sex, and HIV: social and contextual factors, meta-analysis of published interventions, and implications for practice and research. Psychol Bull 2002; 128: 851-85.

44. Tucker JS, Kanouse DE, Miu A, Miu A, Koegel P, Sullivan G. HIV risk behavior and their correlates among HIV-positive adults with serious mental illness. AIDS Behav 2003; 7:29-40.

45. Meade CS. Sexual risk behavior among persons dually diagnosed with severe mental illness and substance use disorder. J Subst Abuse Treat 2006; 30:147-57.
46. Devieux JG, Malow R, Lerner BG, Dyer JG, Baptista L, Lucenko B, et al. Triple jeopardy for HIV: substance using severely mentally ill adults. J Prev Interv Community 2007; 33:5-18.

47. Wainberg ML, McKinnon K, Elkington KS, Mattos PE, Mann CG, Pinto DE. Prevalence of HIV risk and protective factors among adults with SMI in Brazil. World Psychiatry; in press.

48. Chopra MP, Eranti SS, Chandra PS. HIV-related risk behaviors among psychiatric inpatients in India. Psychiatr Serv 1998; 49:823-5.

49. Brunette MF, Rosenberg SD, Goodman LA, Mueser KT, Osher FC, Vidaver R, et al. HIV risk factors among people with severe mental illness in urban and rural areas. Psychiatr Serv 1999; 50:556-8.

50. Coverdale JH, Turbott SH, Roberts H. Family planning needs and STD risk behaviors of female psychiatric outpatients. Br J Psychiatry 1997; 191: 69-72.

51. Davidson S, Judd F, Folley D, Hocking B, Thompson S, Hyland B. Risk factors for HIV/AIDS and hepatitis $\mathrm{C}$ among the chronically mentally ill. Aust N Z J Psychiatry 2001; 35:203-9.

52. Weinhardt LS, Carey MP, Carey KB, Maisto SA, Gordon CM. The relation of alcohol use to HIV-risk sexual behavior among adults with severe and persistent mental illness. J Consult Clin Psychol 2001; 69:77-84

53. Chuang HT, Atkinson M. AIDS knowledge and high-risk behavior in the chronic mentally ill. Can J Psychiatry 1996; 41:269-72.

54. Carey MP, Carey KB, Weinhardt LS, Gordon CM. Behavioral risk for HIV infection among adults with severe mental illness: patterns and psychological antecedents. Community Ment Health J 1997; 33:133-42.

55. Levounis P, Galanter M, Dermatis H, Hamowy A DeLeon G. Correlates of HIV transmission risk factors and considerations for interventions for homeless, chemically addicted and mentally ill patients. J Addict Dis 2002; 21:61-72.

56. Rahav M, Nuttbrock L, Rivera J, Link B. HIV infection risks among homeless, mentally ill, chemically misusing men. Subst Use Misuse 1998; 33:1407-26.

57. Cournos F, Guido J, Coomaraswamy S, MeyerBahlburg H, Sugden R, Horwath W. Sexual activity and risk of HIV infection among patients with schizophrenia. Am J Psychiatry 1994; 151:228-32.

58. Menon A, Pomerantz S, Harowitz S, Applebaum S, Nuthi U, Peacock E. The high prevalence of unsafe sexual behaviors among acute psychiatric inpatients. J Nerv Ment Dis 1994; 182:661-6.

59. Susser E, Valencia E, Miller M, Tsai WY, MeyerBahlburg H, Conover S. Sexual behavior of homeless mentally ill men at risk for HIV. Am J Psychiatry 1995; 152:583-7.

60. Kalichman SC, Kelly JA, Johnson JR, Bulto M. Factors associated with risk for HIV infection among chronic mentally ill adults. Am J Psychiatry 1994; 151:221-7.

61. Thompson SC, Checkley GE, Hocking JS, Crofts N, Mijch AM, Judd FK. HIV risk behavior in HIV testing of psychiatric patients in Melbourne. Aust N Z J Psychiatry 1997; 31:566-76. 
62. Grassi L, Peron L, Ferri S, Pavanati M. Human Immunodeficiency Virus-related risk behavior among Italian psychiatric inpatients. Compr Psychiatry 1999; 40:126-30.

63. Susser E, Valencia E, Conover S. Prevalence of HIV infection among psychiatric patients in a New York City men's shelter. Am J Public Health 1993; 83: 568-70.

64. Lagios K, Deane FP. Severe mental illness is a new risk marker for blood-borne viruses and sexually transmitted infections. Aust N Z J Public Health 2007; 31:562-6.

65. Cournos F, McKinnon K. HIV seroprevalence among people with severe mental illness in the United States: a critical review. Clin Psychol Rev 1997; 17:259-69.

66. Dausey DJ, Desai RA. Psychiatric comorbidity and the prevalence of HIV infection in a sample of patients in treatment for substance abuse. J Nerv Ment Dis 2003; 191:10-7.

67. Otto-Salaj LL, Heckman TG, Stevenson LY, Kelly JA. Patterns, predictors, and gender differences in HIV risk among severely mentally ill men and women. Community Ment Health J 1998; 34:175-90.

68. Weinhardt LS, Carey MP, Carey KB. HIV-risk behavior and the public health context of HIV/AIDS among women living with severe mental illness and persistent mental illness. J Nerv Ment Dis 1998; 186:276-82.

69. Chandra PS, Carey MP, Carey KB, Prasada Rao PS, Jairam KR, Thomas T. HIV risk behaviour among psychiatric inpatients: results from a hospital-wide screening study in southern India. Int J STD AIDS 2003; 14:532-8.

70. Katz RC, Watts C, Santman J. AIDS knowledge and high risk behaviors in the chronic mentally ill. Community Ment Health J 1994; 30:395-402.

71. Menon AS, Pomerantz S. Substance use during sex and unsafe sexual behaviors among acute psychiatric inpatients. Psychiatr Serv 1997; 48:170-2.

72. Weinhardt LS, Otto-Salaj LL, Brondino MJ, Norberg M, Kalichman SC. Sex-related alcohol expectancies predict HIV risk behavior among adults with severe mental illness. Psychol Addict Behav 2002; 16:64-7.

73. Kessler RC, Chiu WT, Demler O, Merikangas KR, Walters EE. The prevalence, severity, and comorbidity of 12-month DSM-IV disorders in the National Comorbidity Survey Replication. Arch Gen Psychiatry 2005; 62:617-27.

74. Regier DA, Farmer ME, Rae DS, Locke BZ, Keith SJ, Judd LL. Comorbidity of mental disorders with alcohol and other drug use disorders: results from the Epidemiologic Catchment Area (ECA) Study. JAMA 1990; 264:2511-8.

75. Clark RE, Samnaliev M, McGovern MP. Treatment for co-occurring mental and substance use disorders in five state Medicaid programs. Psychiatr Serv 2007; 58:942-8.

76. Harris KM, Edlund MJ. Use of mental health care and substance abuse treatment among adults with co-occurring disorders. Psychiatr Serv 2005; 56:954-9.
77. McKinnon K, Cournos F, Herman R. A lifetime alcohol or other drug use disorder and specific psychiatric symptoms predict sexual risk and HIV infection among people with severe mental illness. AIDS Behav 2001; 5:233-40.

78. Meade CS, Graff FS, Griffin ML, Weiss RD. HIV risk behavior among patients with co-occurring bipolar and substance use disorders: associations with mania and drug abuse. Drug Alcohol Depend 2008; 92:296-300.

79. Susser E, Miller M, Valencia E, Colson P, Roche $\mathrm{B}$, Conover S. Injection drug use and risk of HIV transmission among homeless men with mental illness. Am J Psychiatry 1996; 153:794-8.

80. Sacks MH, Silberstein C, Weiler P, Perry S. HIV-related risk factors in acute psychiatric inpatients. Hosp Community Psychiatry 1990; 4:449-51.

81. Volavka J, Convit A, Czobor P, Douyon R, O'Donnel J, Ventura F. HIV seroprevalence and risk behaviors in psychiatric inpatients. Psychiatry Res 1991; 39: 109-14.

82. Kelly JA, Murphy DA, Bahr GR, Brasfield TL, Davis DR, Hauth AC, et al. AIDS/HIV risk behavior among the chronic mentally ill. Am J Psychiatry 1992; 149:886-9.

83. U.S. Department of Health and Human Services. National household survey on drug abuse: main findings. Washington DC: U.S. Government; 1995.

84. Zafrani M, McLaughlin DG. Knowledge about AIDS. Hosp Community Psychiatry 1990; 41:1261.

85. McKinnon K, Cournos F. HIV infection linked to substance use among hospitalized patients with severe mental illness. Psychiatr Serv 1998; 49:1269.

86. Otto-Salaj LL, Stevenson LY. Influence of psychiatric diagnoses and symptoms on HIV risk behavior in adults with serious mental illness. AIDS Read 2001; 11:197-204,206-8.

87. Kelly JA, Murphy DA, Sikkema KJ, Somlai AM, Mulry GW, Fernandez MI, et al. Predictors of high and low levels of HIV risk behavior among adults with chronic mental illness. Psychiatr Serv 1995; 46:813-8.

88. Kim A, Galanter M, Castaneda R, Lifshutz H, Franco. Crack cocaine use and sexual behavior among psychiatric inpatients. Am J Drug Alcohol Abuse 1992; 18:235-46.

89. McDermott BE, Sautter Jr. FJ, Winstead DK, Quirk T. Diagnosis, health beliefs, and risk of HIV infection in psychiatric patients. Hosp Community Psychiatry 1994; 46:580-5.

90. Hanson M, Kramer TH, Gross W, Quintana J, Li P-W, Asher R. AIDS awareness and risk behaviors among dually disordered adults. AIDS Educ Prev 1992; 4:41-51.

91. Knox MD, Boaz TL, Friedrich MA, Dow MG. HIV risk factors for persons with serious mental illness. Community Ment Health J 1994; 30:551-63.

92. Steiner J, Lussier R, RosenblattW. Knowledge about and risk factors for AIDS in a day hospital population. Hosp Community Psychiatry 1992; 43:734-5.

93. Grassi L, Biancosino B, Righi R, Finotti L, Perón L. Knowledge about HIV transmission and prevention among Italian patients with psychiatric disorders. Psychiatr Serv 2001; 52:679-81. 
94. Ogunsemi OO, Lawal RA, Okulate GT, Alebiosu CO, Olatawura MO. A comparative study of HIV/AIDS: the knowledge, attitudes, and risk behaviors of schizophrenic and diabetic patients in regard to HIV/AIDS in Nigeria. MedGenMed 2006; 8:42.

95. Bear JW, Dwyer P, Lewitter-Koehler S. Knowledge about AIDS among psychiatric inpatients. Hosp Community Psychiatry 1988; 39:986-8.

96. Strauss JL. Knowledge and risks of human immunodeficiency virus transmission among veterans with severe mental illness. Mil Med 2006; 171: 325-30.

97. Vanable PA, Carey MP, Carey KB, Maisto SA. Differences in HIV-related knowledge, attitudes, and behavior among psychiatric outpatients with and without a history of sexually transmitted infection. J Prev Interv Community 2007; 33:79-94.

98. Koen L, Niehaus DJH, Emsley RA. Negative symptoms and HIV/AIDS risk-behavior knowledge in schizophrenia. Psychosomatics 2007; 48:128-34.

99. Fisher JD, Fisher WA, Bryan AD, Misovich SJ. Information-motivation-behavioral skills modelbased HIV risk behavior change intervention for inner-city high school youth. Health Psychol 2002; 21:177-86.

100. Chen CH. Seroprevalence of human immunodeficiency virus infection among Chinese psychiatric patients in Taiwan. Acta Psychiatr Scand 1994; 89:441-2.

101. Tharyan P, Ramalingam S, Kannangai R, Sridharan G, Muliyil J, Tharyan A. Prevalence of HIV infection in psychiatric patients attending a general hospital in Tamil Nadu, South Africa. AIDS Care 2003; 15:197-205.

102. Dasananjali T. The prevalence of HIV infection among mentally ill offenders in Thailand. J Med Assoc Thai 1994; 77:257-60.

103. Hutchinson GA, Simeon DT. HIV infection rates and associated factors in high risk patients admitted to a psychiatric hospital in Trinidad and Tobago. West Indian Med J 1999; 48:129-31.

104. Acuda SW, Sebit MB. Serostatus surveillance testing of HIV-I infection among Zimbabwean psychiatric inpatients, in Zimbabwe. Cent Afr J Med 1996; 42:254-7.
105. Di Nardo V, Petrosillo N, Ippolito G, Bonaventura ME, Puro V, Chiaretti B, et al. Prevalence and incidence of hepatitis $B$ virus, hepatitis $C$ virus and human immunodeficiency virus among personnel and patients of a psychiatric hospital. Eur J Epidemiol 1995; 11:239-42.

106. Beyer J, Taylor L, Gersing K, Krishnan KR. Prevalence of HIV infection in a general psychiatric outpatient population. Psychosomatics 2007; 48: 31-7.

107. Naber D, Pajonk FG, Perro C, Löhmer B. Human immunodeficiency virus antibody test and seroprevalence in psychiatric patients. Acta Psychiatr Scand 1994; 89:358-61.

108. Schwartz-Watts D, Montgomery LD, Morgan DW. Seroprevalence of human immunodeficiency virus among inpatient pretrial detainees. Bull Am Acad Psychiatry Law 1995; 23:285-8.

109. Stewart DL, Zuckerman CJ, Ingle JM. HIV seroprevalence in a chronically mentally ill population. J Natl Med Assoc 1994; 86:519-23.

110. Zamperetti M, Goldwurm GF, Abbate E, Gris T, Muratori S, Vigo B. Attempted suicide and HIV infection: epidemiological aspects in a psychiatric ward. Int Conf AIDS 1990; 6:182.

111. Krakow DS, Galanter M, Dermatis H, Westereich LM. HIV risk factors in dually diagnosed patients. Am J Addict 1998; 7:74-80.

112. Dinwiddie S, Shicker L, Newman T. Prevalence of hepatitis $\mathrm{C}$ among psychiatric patients in the public sector. Am J Psychiatry 2003; 160:172-4.

113. Butterfield M, Bosworth $\mathrm{H}$, Stechuchak $\mathrm{K}$, Frothingham R, Bastian LA, Meador KG, et al. Racial differences in hepatitis $\mathrm{B}$ and hepatitis $\mathrm{C}$ and associated risk behaviors in veterans with severe mental illness. J Natl Med Assoc 2004; 96:43-52.

114. Meyer JM. Prevalence of hepatitis A, hepatitis B, and HIV among hepatitis C-seropositive state hospital patients: results from Oregon State Hospital. J Clin Psychiatry 2003; 64:540-5.

Submitted on $02 / \mathrm{Abr} / 2008$ Final version resubmitted on $04 / J u n / 2008$ Approved on 24/Jun/2008 